Article

\title{
Engineering Concanavalin B to Release Bioactive Peptides against Metabolic Syndrome
}

\author{
Diego Armando Maldonado-Torres ${ }^{1}$, G. Janet Jara-Romero ${ }^{1}$, Flor de Fátima Rosas-Cárdenas ${ }^{1}$, \\ D. Alejandro Fernández-Velasco ${ }^{2, *}$ and Silvia Luna-Suárez ${ }^{1, *}$
}

1 Centro de Investigación en Biotecnología Aplicada, Instituto Politécnico Nacional, CIBA-IPN, Carretera estatal Tecuexcomac-Tepetitla Km. 1.5, Tepetitla 90700, Mexico; darmanmalto@gmail.com (D.A.M.-T.); janet_16@live.com.mx (G.J.J.-R.); frosasc@ipn.mx (F.d.F.R.-C.)

2 Laboratorio de Fisicoquímica e Ingeniería de Proteínas, Departamento de Bioquímica, Facultad de Medicina, UNAM, Ciudad de México 04510, Mexico

* Correspondence: fdaniel@unam.mx (D.A.F.-V.); sluna@ipn.mx or silvials2004@yahoo.com.mx (S.L.-S.); Tel.: +52-55-56232259 (D.A.F.-V.); +52-55-729-6300 (ext. 87814) (S.L.-S.)

check for updates

Citation: Maldonado-Torres, D.A.; Jara-Romero, G.J.; Rosas-Cárdenas, F.d.F.; Fernández-Velasco, D.A.;

Luna-Suárez, S. Engineering

Concanavalin B to Release Bioactive Peptides against Metabolic Syndrome. Foods 2021, 10, 1554. https:/ / doi.org/ 10.3390 /foods 10071554

Academic Editors: Chibuike

C. Udenigwe and Rotimi Aluko

Received: 15 May 2021

Accepted: 23 June 2021

Published: 5 July 2021

Publisher's Note: MDPI stays neutral with regard to jurisdictional claims in published maps and institutional affiliations.

Copyright: (c) 2021 by the authors. Licensee MDPI, Basel, Switzerland. This article is an open access article distributed under the terms and conditions of the Creative Commons Attribution (CC BY) license (https:// creativecommons.org/licenses/by/ $4.0 /)$

\begin{abstract}
Metabolic syndrome is a severe public health issue characterized by multiple metabolic disturbances. Current treatments prescribe a particular drug for each of them, producing multiple side effects. As a first step towards a more integral approach, we applied our recently described methodology to design single proteins, based in the Concanavalin B scaffold (1CNV), that contain several bioactive peptides (BPs), including antioxidant and lipid-lowering activities as well as inhibitors of dipeptidyl peptidase IV (DPPIV) and the angiotensin converting enzyme. Modified Concanavalin (CNV44), the designed protein that showed the best in silico properties, was expressed in high yields in E. coli and purified to homogeneity. After in vitro digestion with gastrointestinal enzymes, all the biological activities tested where higher in CNV44 when compared to the nonmodified protein $1 \mathrm{CNV}$, or to other previous reports. The results presented here represent the first in vitro evidence of a modified protein with the potential to treat metabolic syndrome and open the venue for the design of proteins to treat other non-communicable diseases.
\end{abstract}

Keywords: metabolic syndrome; bioactive peptides; protein engineering; DPPIV; ACEI; antioxidant activity; lipid-lowering

\section{Introduction}

Modern lifestyle is responsible for the increase of non-communicable diseases like obesity and its comorbidities [1] such as metabolic syndrome (MS), characterized by multiple metabolic disturbances such as dyslipidemia, insulin resistance, hypertension, pro-thrombotic state, and proinflammatory state, among others. These disorders act synergically to increase the risk of cardiovascular disease (CVD) and stroke. The actual treatment is based on modification of lifestyle, the pharmacological approach usually includes a particular drug for each of the metabolic disturbance, causing many side effects [2].

Functional foods are those with beneficial effects on health beyond nutrition and energetic purposes [3]; the design of functional foods, including proteins and peptides, is a strategy to give options to people with health issues [4].

Bioactive peptides (BPs) have been proposed as candidates to treat MS. BPs are short sequences of amino acids "encrypted" within a parental protein that must be released, by enzymatic hydrolysis or other means, in order to show some positive biological effect [5]. BPs can be released from every food that contains proteins such as milk, meat, fish, cereals, pseudocereals, and legumes. Numerous biological activities from bioactive peptides have been described, with the advantage of not presenting side effects [6]. BPs against all the metabolic disturbances present in MS such as antihypertensive peptides and DPPIV inhibitors have been reported. 
Some researchers have designed proteins with the final purpose of carrying bioactive peptides for specific diseases; for example, Takenaka et al. [7] inserted the cholesterol lowering BPs LPYPR in soy pro-glycinin and confirmed that the BP was released after tryptic and chymotryptic digestion. Another approach is to design a completely de novo protein, as reported by Sengqi et al. [8] who built an antihypertensive protein by assembling in tandem, with linker residues between them, previously reported BPs that account for the specificities of gastrointestinal enzymes.

We have previously reported that knowledge of bioactive peptides in combination with protein engineering can be used as a tool with the potential to treat, ameliorate, or prevent MS through the design of a functional compound that enriches a food [9]. These modified proteins can then be used for in vivo trials to test in vivo the biological activity in an organism. As a first step toward this goal, in this work we employed Concanavalin B (CVN) as a scaffold and applied the methodology to the design of a protein, able to carry bioactive peptides, that can be released after an in vitro gastrointestinal digestion with in vitro effects on some metabolic activities related to MS.

\section{Materials and Methods}

\subsection{Chemicals}

All chemicals used were analytical grade. Pepsin from porcine gastric mucosa (>2500 U/mg), pancreatin from porcine pancreas, 3-hydroxy-3-metyl glutaryl-CoA reductase human, NADPH tetrasodium, DL-3Hydroxy-3-methylglutaryl coenzyme A sodium salt hydrate, Angiotensin Converting Enzyme from rabbit lung 2.0 units/mg protein, $N$-Hippuryl-His-Leu hydrate were purchased from Sigma-Aldrich Chemical Company (St. Louis, MO, USA). NdeI and BamHI restriction enzymes were purchased from Thermofisher Scientific, Waltham, MA, USA.

\subsection{Bioactive Peptides Selection}

ACEI peptides and inhibitors of DPPIV peptides were selected from the BIOPEP database [10]; only di- and tripeptides were selected, dipeptides were given priority. These peptides were sorted via their reported $\mathrm{IC}_{50}$, and those peptides with in vivo activity were given priority. Antioxidant and lipid-lowering peptides were searched and selected based on the literature. Only those with high activity where selected. To evaluate resistance to gastrointestinal enzymes, selected peptides were submitted to in silico gastrointestinal digestion with BIOPEP and PeptideCutter tools, choosing pepsin $\mathrm{pH}$ 1.3, trypsin, and chymotrypsin. Only those that revealed in silico resistance to digestive enzymes were reviewed.

\subsection{In Silico Design}

We have previously reported a strategy to design a protein with properties against metabolic syndrome [9]. The Figure 1 summarizes the workflow.

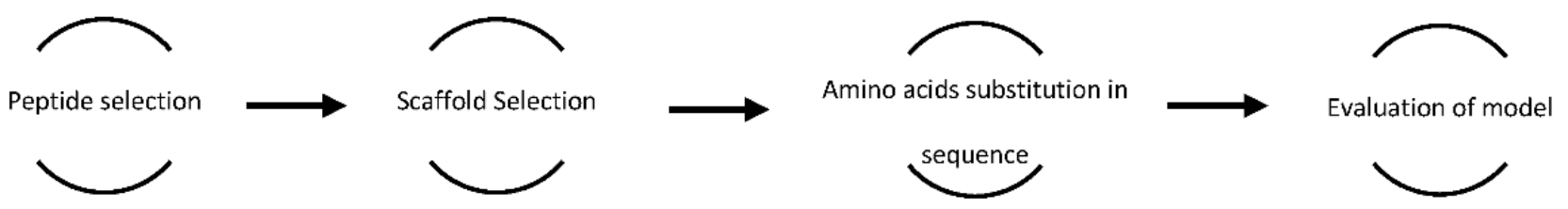

Figure 1. Stages followed to design a protein against metabolic syndrome.

Briefly, we searched in the literature and in the BIOPEP-UWM database for BPs with activity against metabolic disturbances present in metabolic syndrome like angiotensin converting enzyme inhibitory activity (ACE-I), dipeptidyl peptidase IV inhibitory activity (DPPIV-I), antioxidants, and lipid-lowering effects. After obtaining some sequences from vegetable proteins from the UNIPROT database https: / www.uniprot.org/ (accessed on 1 February 2017), we searched for the presence of selected BPs into the sequences and 
calculated the parameter $A$ ( $A$ is the relative frequency of bioactive peptides able to treat metabolic syndrome) with the next equation:

$$
A=(\mathrm{a} / \mathrm{N})
$$

where "a" is the number of peptides and $\mathrm{N}$ is total number of amino acids. The protein with the higher $A$ value was selected as scaffold.

To obtain a carrier protein that releases bioactive peptides, we considered the specificities of the following gastrointestinal enzymes, pepsin (Phe or Leu), trypsin (Arg or Lys), and chymotrypsin (aromatics and Leu). In silico evaluation was carried out with Protparam ExPASy-ProtParam tool to assess in vitro stability, VADAR VADAR (wishartlab.com) (accessed on 2-4 March 2021) to evaluate free folding energy (FFE) and Arpeggio Arpeggio (unimelb.edu.au) (accessed on 15-20 March and 10-15 April 2021) to compare changes in molecular interactions.

\subsection{Expression and Purification}

\subsubsection{Extraction of Genomic DNA from Canavalia Ensiformis}

Genomic DNA was extracted from leaves of Canavalia ensiformis. Briefly, a sample of tissue was frozen with liquid nitrogen, mixed with $500 \mu \mathrm{L}$ of lysis solution $(200 \mathrm{mM}$ Tris $\mathrm{HCl} \mathrm{pH} \mathrm{8.5,} 250 \mathrm{mM} \mathrm{NaCl}, 2.5 \mathrm{mM}$ EDTA and 1\% SDS), $500 \mu \mathrm{L}$ of phenol: chloroform was added and vortexed for one minute and then centrifuged to $12,000 \mathrm{rpm}$ for $10 \mathrm{~min}$, the aqueous phase was separated and mixed with $3 \mathrm{M}$ of sodium acetate $\mathrm{pH} 4.8$ (1:10 ratio) and isopropanol (1:2 ratio), the mixture was incubated to $-20^{\circ} \mathrm{C}$ for $2 \mathrm{~h}$ and then centrifuged in the same conditions, supernatant was discarded and pellet was resuspended in $70 \%$ of ethanol and centrifuged as previously described, supernatant was discarded, and the pellet resuspended in deionized water.

\subsubsection{Primers Design and Extraction of Concanavalin B Gen}

With the cDNA sequence reported by Schelesier et al. (1996) [11] we designed the forward $5^{\prime}$ ggcatatggacataagttctacagag $3^{\prime}$ and reverse $5^{\prime}$ ggggatccctaagataacgtataatg $3^{\prime}$ primers, with sites for NdeI and Bam HI restriction enzymes, to amplify Concanavalin B (The PDB Code for Concanavalin $\mathrm{B}, 1 \mathrm{CNV}$, is used throughout the text as acronym for the protein.); the primers were synthesized by T4Oligo (México). PCR was conducted at a $94{ }^{\circ} \mathrm{C}$ denaturation temperature for $2 \mathrm{~min}$ and alignment temperature of $57^{\circ} \mathrm{C}$ for 35 cycles, amplicon was visualized on a $1 \%$ agarose gel, and to confirm the identity was sequenced by dideoxynucleotide label technique by LANBAMA (IPICYT, México). The amplicon was purified from the gel and cloned in pET15b plasmid; this construct was named pET15CNVR.

\subsubsection{Expression and Purification of Recombinant Concanavalin (CNVR) and Modified Concanavalin (CNV44)}

The gen for CNV44 was designed and sent for synthesis and cloning in pET15b at GenScript ${ }^{\circledR}$. This construct was named pET15CNV44.

E. coli BL21-CodonPlus(DE3)-RIL strain (Stratagene) was transformed by thermal shock with the plasmids pET15CNVR or pET15CNV44 and the proteins (CNVR or CNV44, respectively) were expressed using potato medium [12] at $37^{\circ} \mathrm{C}$ for $9 \mathrm{~h}$ at constant agitation, protein expression was induced with lactose $0.5 \%$ final concentration once the culture reached $0.3 \mathrm{DO}$ at $600 \mathrm{~nm}$, thereafter, the medium was centrifuged at $10,000 \mathrm{rpm}$ for $20 \mathrm{~min}$, pellets were washed with distilled water and later sonicated in phosphate buffer $20 \mathrm{mM}$ $\mathrm{pH} 7.5$, pellets were washed once again and the soluble fraction extracted with phosphate buffer $20 \mathrm{mM}+\mathrm{NaCl} 0.2 \mathrm{M}$, insoluble fraction was extracted with urea $6 \mathrm{M}$. For CNVR, differential precipitation with ammonium sulfate was required. Finally, CNV44 and CNVR were dialyzed against MilliQ water. Final pellets were stored at $-10{ }^{\circ} \mathrm{C}$ until further analysis. All samples were subjected to $14 \%$ SDS-PAGE [13]. The proteins were visualized with Coomassie Brilliant Blue G-250. Quantitative analysis of the recombinant proteins accumulation was carried out by densitometry using Image Lab 4.0 (Bio-Rad). 


\subsection{Simulated Gastrointestinal Digestion}

Simulated gastrointestinal digestion (SGID) was based on the report by Vilacundo et al. (2018) [14]; briefly, purified proteins were diluted in water, to start gastric phase $\mathrm{pH}$ was adjusted to 2.0 with $\mathrm{HCl}$, pepsin was added in a $250 / 1$ substrate/enzyme ratio, the mix was incubated for $2 \mathrm{~h}$ in constant agitation, following by the intestinal phase, where $\mathrm{Na}_{2} \mathrm{CO}_{3}$ was added until pH 7.0 was reached, then pancreatin was added in a ratio 200/1 $\mathrm{S} / \mathrm{E}$ and was incubated for $12 \mathrm{~h}$, both gastric and intestinal phases was carried out at $37^{\circ} \mathrm{C}$. To stop reaction, the mix was heated to $95^{\circ} \mathrm{C}$ for $5 \mathrm{~min}$.

\subsection{In Vitro Activities}

2.6.1. DPPH

DPPH scavenging assay was conducted according to Ajibola et al. (2011) [15], $20 \mu \mathrm{L}$ of different concentrations of hydrolyzed and unhydrolyzed CNV44 and CNVR were mixed with ethanolic solution of DPPH $150 \mu \mathrm{M}$, the reaction was incubated for $30 \mathrm{~min}$ in dark at room temperature, then absorbance was followed at $515 \mathrm{~nm}$, percentage of inhibition (\% I) was calculated with the next equation:

$$
\% \mathrm{I}=1-(\mathrm{AbsM} / \mathrm{Abs} 0) \times 100
$$

where $\mathrm{AbsM}$ is sample absorbance and $\mathrm{Abs} 0$ is the negative control absorbance.

\subsubsection{ABTS}

We adapted the 96-well microplate technique reported by Re et al. (1999) [16], a solution containing $7 \mathrm{mM}$ of ABTS and $2.45 \mathrm{mM}$ of potassium persulfate was reposed at room temperature in dark for $16 \mathrm{~h}$ before the assay, this solution was diluted in ethanol until the absorbance at $734 \mathrm{~nm}$ was $0.7 \mathrm{UA}$. Different concentrations of hydrolyzed and unhydrolyzed CNV44 and CNVR were tested, $20 \mu \mathrm{L}$ of each concentration was mixed with $200 \mu \mathrm{L}$ of ABTS *, after 6 min of incubation at room temperature absorbance was read at $734 \mathrm{~nm}$. Trolox was used as standard. Equation (2) was used to calculate \%I.

\subsection{3. $\mathrm{Fe}^{++}$Chelation}

$\mathrm{Fe}^{++}$chelation capacity was conducted according to Adjimani and Asare (2015) [17] with some modifications. Briefly, $50 \mu \mathrm{L}$ of $\mathrm{FeSO}_{4}$ and $50 \mu \mathrm{L}$ of sample were mixed and incubated for $10 \mathrm{~min}$, thereafter $100 \mu \mathrm{L}$ of FerroZine was added and the solution was incubated for 10 more minutes, absorbance was then read at $562 \mathrm{~nm}$, to calculate percentage of quelation $(\% \mathrm{Q})$ we used the next equation:

$$
\% \mathrm{Q}=1-(\mathrm{AbsM} / \mathrm{Abs} 0) \times 100
$$

where $\mathrm{AbsM}$ is sample absorbance and $\mathrm{Abs} 0$ is the negative control absorbance.

\subsubsection{Inhibition of Angiotensin Converting Enzyme}

To evaluate ACEI activity we used the technique reported by Li et al. (2004) [18], $4 \mu \mathrm{L}$ of samples at different concentrations were mixed with $10 \mu \mathrm{L}$ of HHL in borate buffer $\mathrm{pH} 8.3$ and incubated at $37^{\circ} \mathrm{C}$ for $5 \mathrm{~min}$, then $2 \mu \mathrm{L}$ of ACE was added and the solution was incubated at the same temperature for 30 more minutes, reaction was stopped with $20 \mu \mathrm{L}$ of $\mathrm{HCl} 1 \mathrm{M}$, in order to detect hippuric acid, $48 \mu \mathrm{L}$ of quinoline and $16 \mu \mathrm{L}$ of benzenesulfonyl chloride were added and the solution was incubated for $30 \mathrm{~min}$ at $30^{\circ} \mathrm{C}$ in dark, then absolute ethanol was added and incubated at the same condition of previous step, absorbance was then followed at $492 \mathrm{~nm}$. Percentage inhibition (\%I) was calculated with the next equation:

$$
\% \mathrm{I}=(\mathrm{B}-\mathrm{A} / \mathrm{B}-\mathrm{C}) \times 100
$$

where $\mathrm{A}$ is sample absorbance, $\mathrm{B}$ is control absorbance and $\mathrm{C}$ is blank absorbance. 


\subsubsection{Inhibition of DPPIV}

To assess DPPIV inhibitory activity, we adapted the technique reported by Lacroix and Li-Chan (2014) [19]. Briefly, $50 \mu \mathrm{L}$ of samples with variable concentrations were mixed with Gp-pNA $0.2 \mathrm{M}$ in Tris- $\mathrm{HCl} 100 \mathrm{mM} \mathrm{pH} 8$ and incubated for $10 \mathrm{~min}$ at $37^{\circ} \mathrm{C}$, reaction started by adding $50 \mu \mathrm{L}$ of DPPIV enzyme at $0.005 \mathrm{U} / \mathrm{mL}$ at same temperature for $1 \mathrm{~h}$, absorbance was measured at $405 \mathrm{~nm}$. \% I was calculated using Equation (4).

\subsubsection{Inhibition of HMGR}

For HMGR inhibition the methodology of Lin et al. (2014) [20] was adapted as follows: different concentrations of samples were mixed with NADPH $200 \mu \mathrm{M}, \mathrm{HMGCoA} 10 \mu \mathrm{M}$, and $2 \mu \mathrm{L}$ of human-HMGR at $0.3 \mathrm{mg} / \mathrm{mL}$, final concentrations and $200 \mu \mathrm{L}$ final volume in phosphate buffer pH 7.4 with EDTA $200 \mathrm{mM}$, the reaction was conducted at $37^{\circ} \mathrm{C}$ and absorbance at $340 \mathrm{~nm}$ was measured every $10 \mathrm{~min}$, the results were expressed in $\mu \mathrm{Mol}$ of NADPH consumed during the reaction.

\subsection{Statistical Analysis}

All analyses were performed in triplicate and average values were calculated. Statistical significances were evaluated using one-way analysis of variance (ANOVA) and LSD test in SAS 9.0 software.

\section{Results}

\subsection{Scaffold Selection and Sequence Modification}

According to our previous peptide selection [9], we searched among some representative vegetable proteins, for those with the major number of BPs in their sequence compared to total number of amino acids ( $A$ value). Concanavalin B (1CNV) from Canavalia ensiformis contain $10 \mathrm{BPs}$ in their sequence $(A=0.033)$ of which seven are antihypertensive (three VY, two EY and two DG), one antioxidant (CG) and two lipid-lowering (DE) (Supplementary Material Table S1) so, we chose Concanavalin B as the scaffold. After in silico gastrointestinal digestion, we observed the profile of peptides with severe reported activities, but none of them were released because they lack the flanking residues required for protease recognition. After identification of BPs, multiple substitutions in adjacent amino acids were made in order to release the BPs on the 1CNV sequence. Ninety-six sequences of $\mathrm{CNV}$ with a total of 13 modifications were generated (Supplementary Material Table S2). Because of a lack of secondary structure and BPs the C-terminal, 16 amino acids were deleted and replaced with the tripeptide IPI. Free folding energy and total contacts reveal the major similarity between Concanavalin B and modified concanavalin number 44, from here on named CNV44 (Table 1). CNV44 was evaluated and a new in silico gastrointestinal digestion revealed a new profile of peptides that included all of the selected peptides (Table 2). A comparison between the 1CNV and CNV44 sequences is presented in Figure 2.

Table 1. Comparison between Native Concanavalin B (1CNV) and the 5 modified versions closer to native Concanavalin B (stability, free folding energy, and total contacts). Instability index is better for in vitro conditions at lower numbers (below 40 is considered stable), FFE = Free Folding Energy.

\begin{tabular}{cccc}
\hline Protein Version & Instability Index & FFE (kcal/mol) & Total Contacts \\
\hline 1 CNV & 36.38 & -287.16 & 16,138 \\
44 & 29.97 & -294.14 & 11,519 \\
40 & 29.71 & -293.44 & 11,510 \\
45 & 30.4 & -293.45 & 11,521 \\
41 & 30.14 & -292.74 & 11,508 \\
68 & 30.4 & -292.23 & 11,467 \\
\hline
\end{tabular}


Table 2. Comparison of BPs profiles between 1CNV and CNV44 after in silico gastrointestinal digestion.

\begin{tabular}{ccc}
\hline Activity & BPs in 1CNV & BPs in CNV44 \\
\hline ACEI & IVF, GK, DY, VR, IR & DG, IVF, VY, GK, IW, IY, IR \\
DPPIV inhibitors & TY, NW, DN, VR, IR, SW, TK, PY, NR & VY, IW, DN, EY, VR, IR, TK, QV, NR, IPI \\
Antioxidant & TY, IR, EL & TY, VY ${ }^{1}$, IR, DW, EL \\
Lipid lowering & - & DE \\
\hline
\end{tabular}

${ }^{1}$ The VY dipeptide has being reported to be antioxidant [21]; however, its main activity is as ACEI [22]. Peptides selected from our previous report are bold [9].

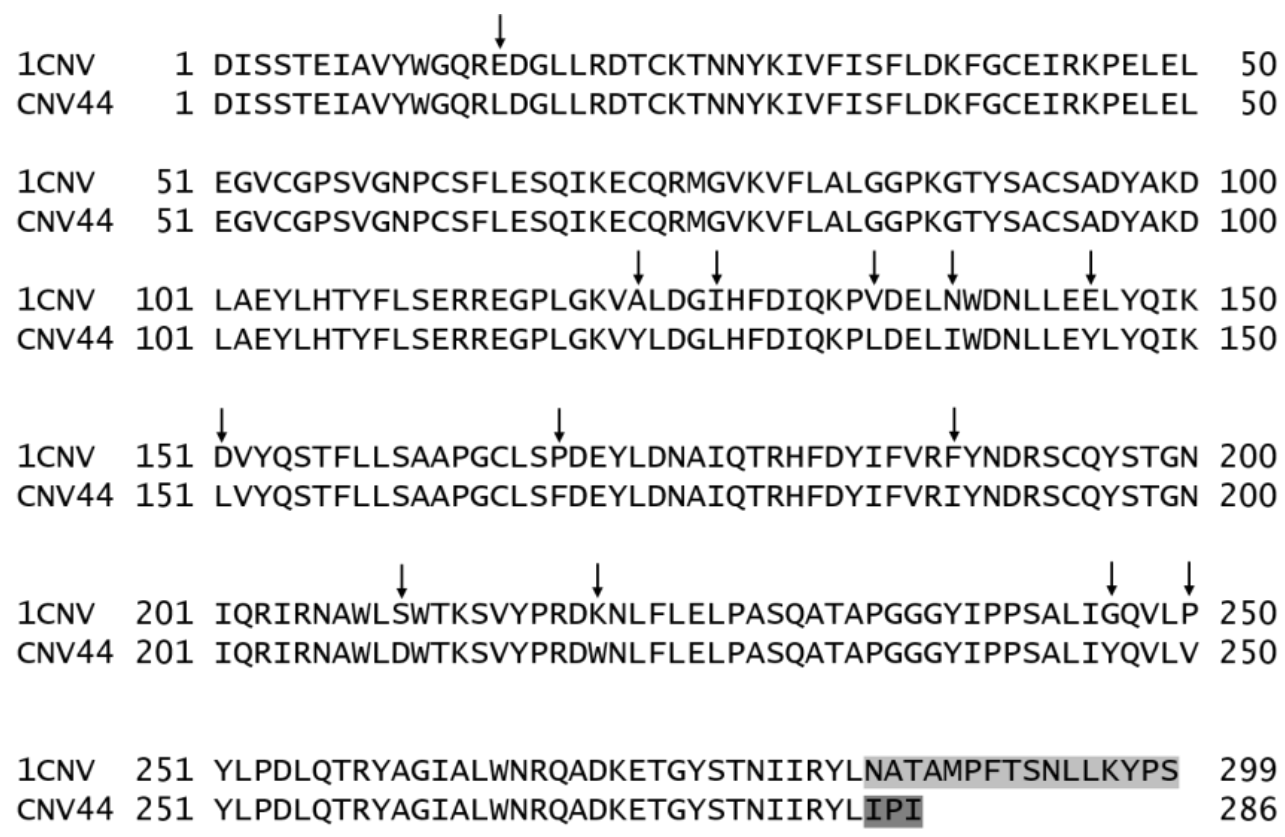

Figure 2. Sequences of Concanavalin B scaffold (1CNV) and Modified Concanavalin (CNV44). Arrows indicate substitution sites. The deleted C-terminal sequence as well as the dipeptidyl peptidase IV (DPPIV) inhibitor that replaces it (IPI) are shown in light gray.

\subsection{Expression and Purification of CNVR and CNV44 \\ 3.2.1. CNVR}

Genomic DNA from Canavalia ensiformis was extracted from fresh leaves. In the agarose gel a $1000 \mathrm{bp}$ fragment was observed (Supplementary Material Figure S1), and sequence analysis of this fragment confirmed its identity as the Concanavalin B gen. The concanavalin B gen was cloned in pET15 plasmid, E. coli BL21 CodonPlus (DE3)-RIL strains were further transformed for expression.

From cells harvested after induction for $6 \mathrm{~h}, \mathrm{CNVR}$ was extracted in the insoluble fraction, and reached a yield of $1400 \pm 10 \mathrm{mg} / \mathrm{L}$, with a productivity of $0.14 \mathrm{mg} / \mathrm{h}$. Recovery and purification are presented in the Figure 3 . The purity in urea $6 \mathrm{M}$ was $96 \%$.

\subsubsection{CNV44}

$\mathrm{CNV} 44$ was expressed and recovered after $6 \mathrm{~h}$ post-induction in insoluble form in urea $6 \mathrm{M}$, the yield was $1460 \pm 20 \mathrm{mg} / \mathrm{L}$ and productivity of $0.2 \mathrm{mg} / \mathrm{h}$, the purity was about $90 \%$ (Figure 4 ).

CNV44 was then precipitated by isoelectric precipitation and ammonium sulfate, last one in $4 \%$ concentration selectively precipitate CNV44 above of $90 \%$ of purity, Figure 5 . 


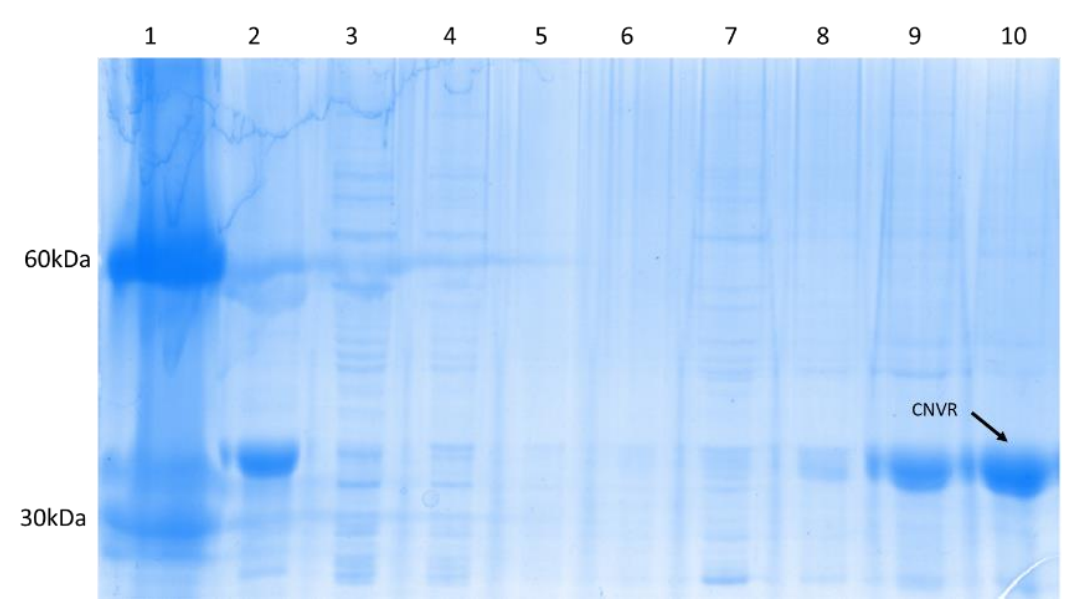

Figure 3. Recombinant Concanavalin (CNVR) Purification. 1 = Molecular marker, 2 = Pellet after expression, 3 = fraction recovered in phosphates buffer, 4-6 = fraction recovered in mercaptoethanol $10 \mathrm{mM}, 7-8=$ fraction recovered in Urea $1 \mathrm{M}, 9-10=$ fraction recovered in urea $6 \mathrm{M}$.

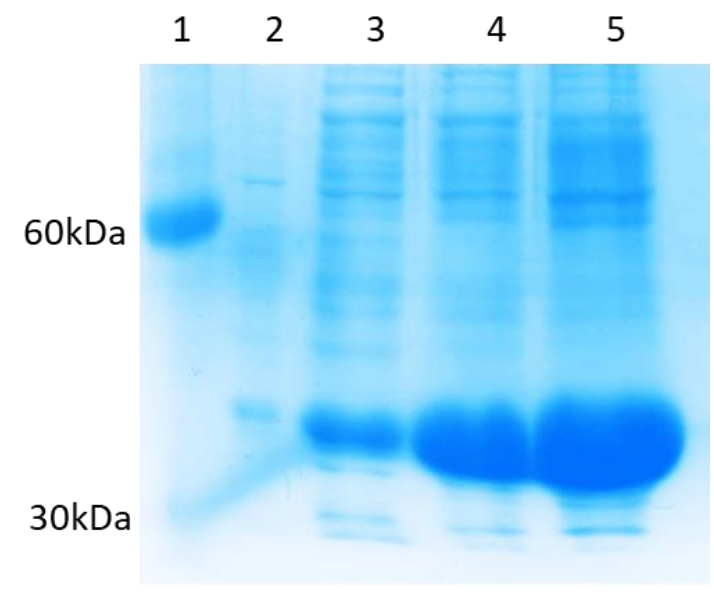

Figure 4. Modified Concanavalin (CNV44) Recovery. 1 = Molecular marker, 2 = Soluble fraction, $3=$ Insoluble fraction urea $2 \mathrm{M}, 4-5=$ Insoluble fraction urea $6 \mathrm{M}$.

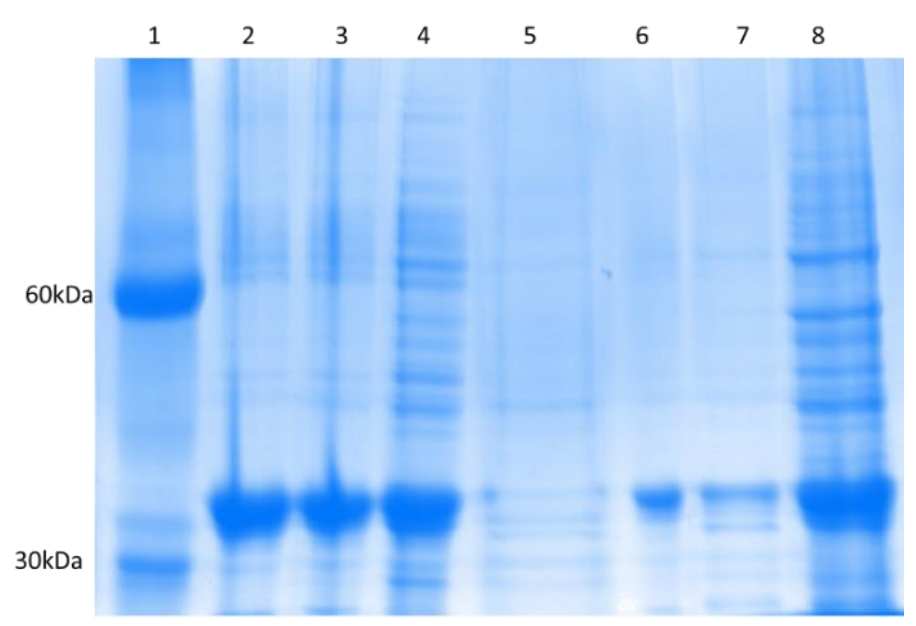

Figure 5. CNV44 Purification. 1 = Molecular marker, 2 = Isoelectric precipitation $\mathrm{pH} 2,3=$ Isoelectric precipitation $\mathrm{pH} 3,4=$ Isoelectric precipitation $\mathrm{pH} 4,5=\mathrm{NaCl} 1 \mathrm{M}, 6=4 \%$ Ammonium sulfate, $7=6 \%$ ammonium sulfate, $8=$ Starter pellet. 


\subsection{In Vitro Activity}

\subsubsection{Antioxidant Activity}

The antioxidant activity assessed with DPPH showed that both CNVR and CNV44 as well as their hydrolysates have a low activity that reaches a maximum of $10 \%$ of inhibition at a maximum concentration $400 \mu \mathrm{g} / \mathrm{mL}$; this maximum activity was found in the hydrolysate of the modified protein (Figure 6).

A

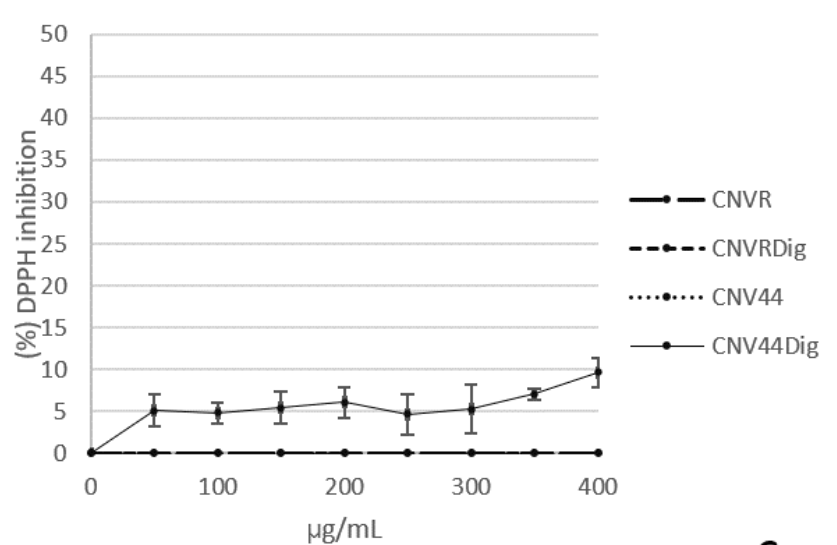

C

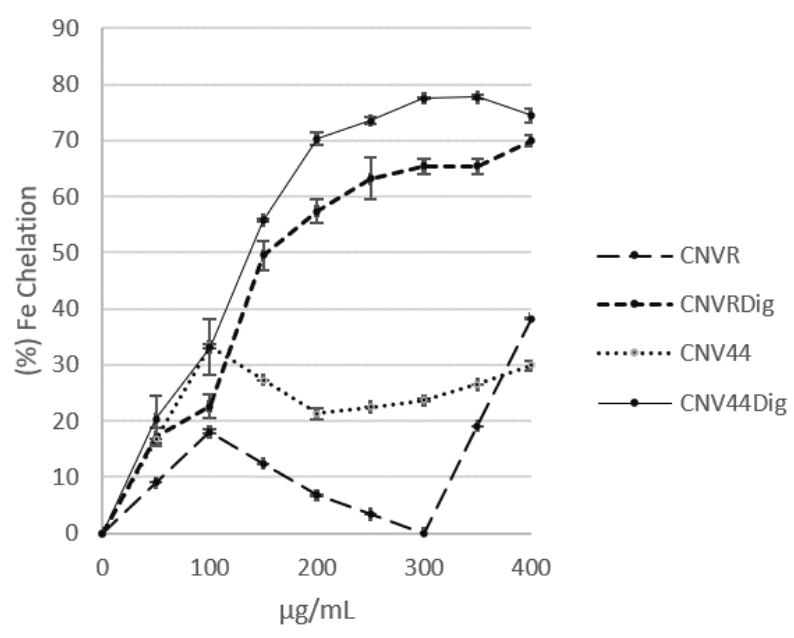

B

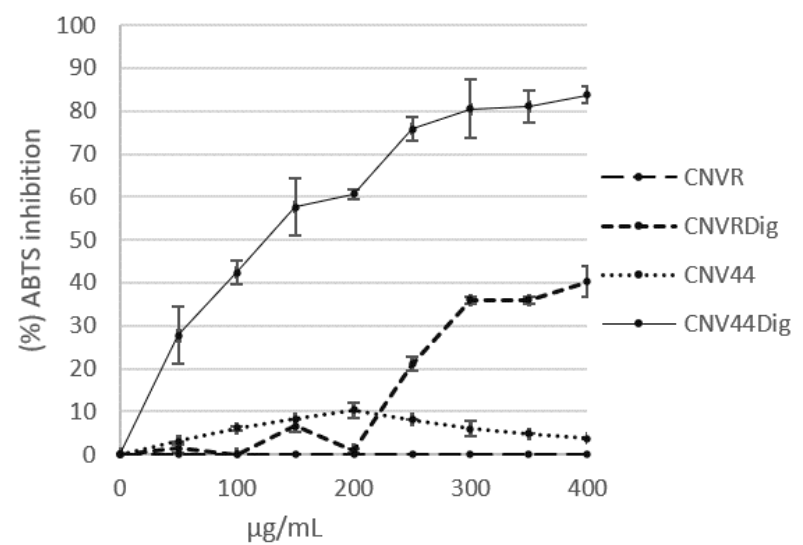


(400 $\mu \mathrm{g} / \mathrm{mL}$ ), higher than CNVR. The hydrolysates of both CNR and CNV44 outperformed their respective non hydrolyzed, digested CNV44 reaches above $94 \%$ of ACEI, significantly higher than digested CNVR. IC50 values for both hydrolysates are $4.5 \pm 0.6$ and $29.3 \pm 2.1$ for CNV44 and CNVR hydrolysates, respectively, so the modified protein is better than the non-modified one.

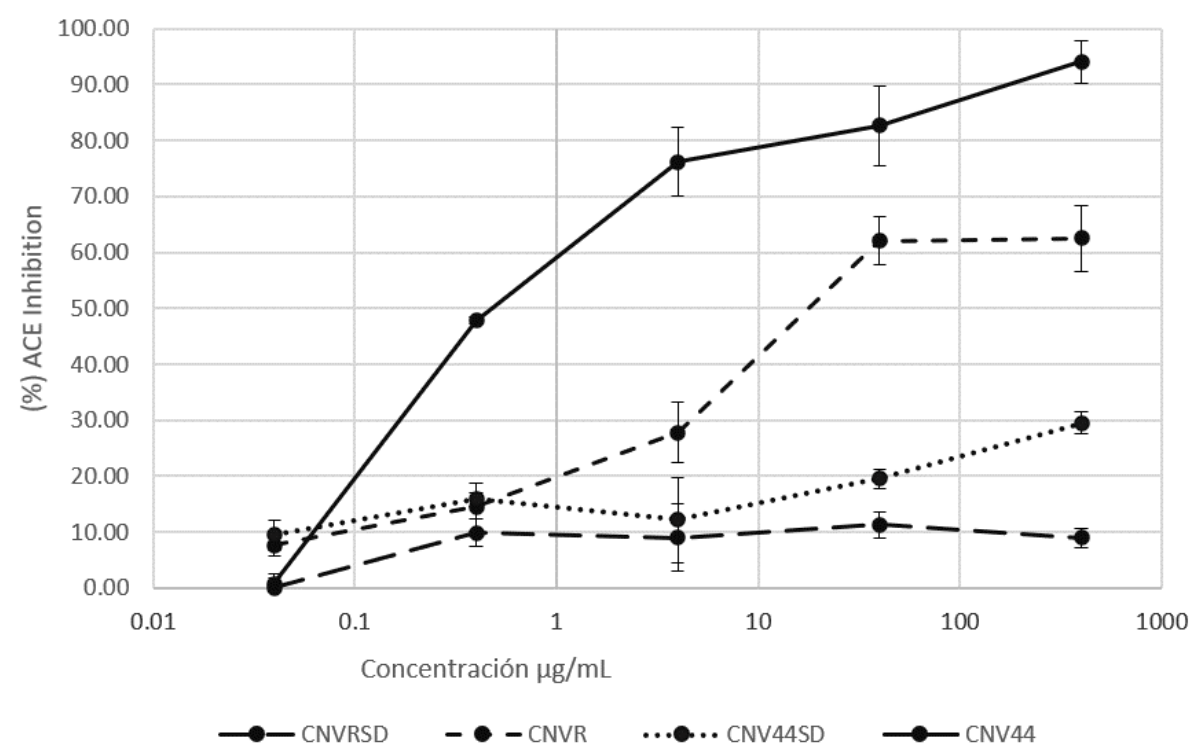

Figure 7. ACEI activity of CNVR and CNV44 and their hydrolysates.

\subsubsection{DPPIV Inhibition Activity}

Proteins CNVR, CNV44, and their hydrolysates were tested to measure their capacity to inhibit DPPIV enzyme. The unhydrolyzed protein showed a DPPIV activity $40 \%$ lower than its hydrolyzed counterpart, which reaches inhibition percentage above $60 \%$ at higher concentrations. IC50 values for hydrolysates are $0.045 \pm 0.001$ for CNVR hydrolysate and $0.033 \pm 0.001$ for CNV44 hydrolysate (Figure 8).

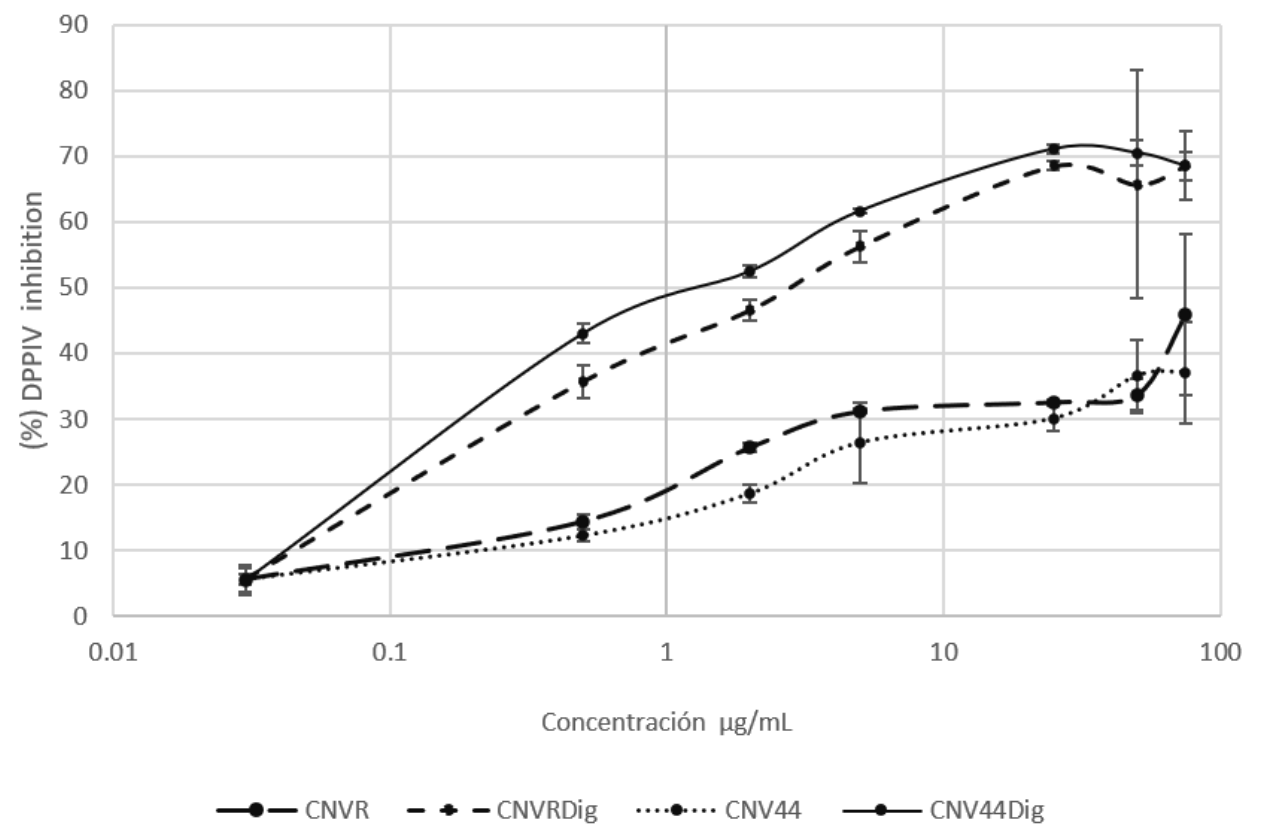

Figure 8. DPPIV inhibitory activity of CNVR and CNV44 and their hydrolysates. 


\subsubsection{HMGCoA Reductase Activity}

First, we measured the depletion of NADPH in the test buffer and the results are presented in Supplementary Figure S2. We found that the absorbance at $340 \mathrm{~nm}$ remains stable for a period of $30 \mathrm{~min}$, time in which is possible follow the consumption of NADPH utilized for HMGR.

The consumption of NADPH by HMGR is presented in Figure 9. In general, the lowest consumption is presented in samples at $100 \mathrm{mg} / \mathrm{mL}$, only after $20 \mathrm{~min}$ the consumption diminished in most cases. Best results were found in both CNVR and CNV44 hydrolysates in the last one, the inhibition of HMGR is evident in $10 \mathrm{~min}$ and stable during all the time lapse.

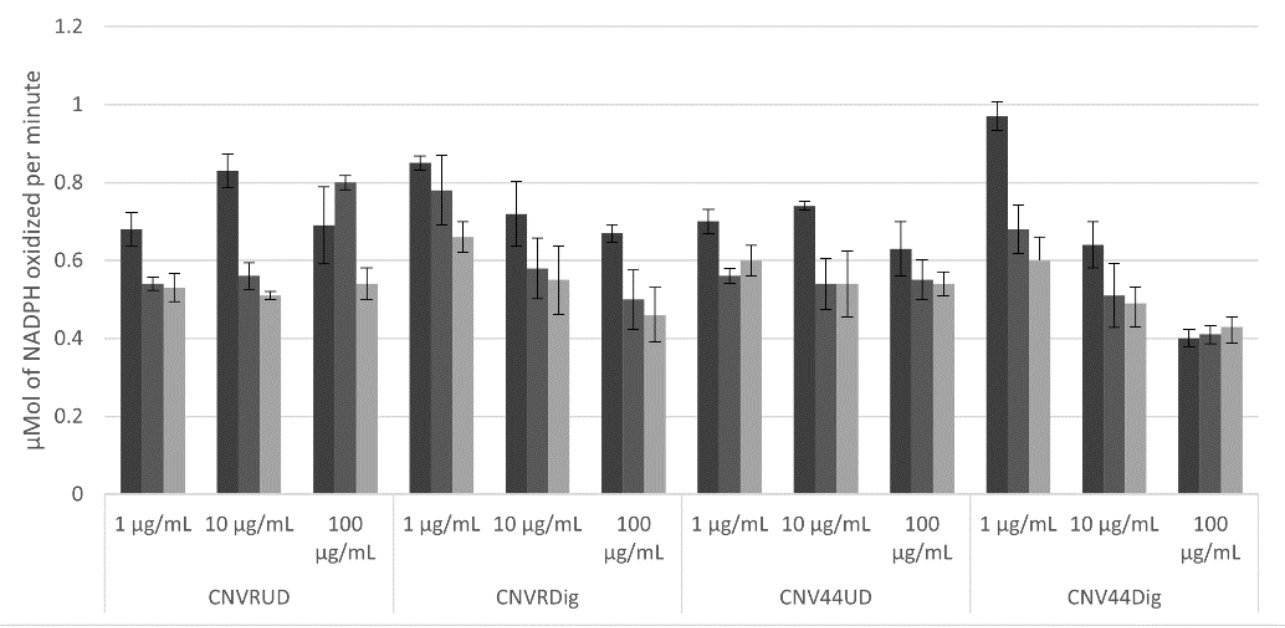

Figure 9. Oxidized NADPH from HMGR in presence of digested and undigested proteins. CNVRUD = Undigested CNVR, CNVRDig = CNVR hydrolyzed, CNV44UD = Undigested CNV44, $\mathrm{CNV} 44 \mathrm{Dig}=\mathrm{CNV} 44$ hydrolyzed. In dark gray after $10 \mathrm{~min}$, in medium gray after $20 \mathrm{~min}$, and light gray after $30 \mathrm{~min}$.

\section{Discussion}

\subsection{Scaffold Selection and Sequence Modification}

We selected short BPs composed by two or three residues to treat metabolic syndrome because the structure-activity relationship reveals that, in general, while shorter in length their activity is higher than those of longer BPs [23]. On the other hand, protein digestion in intestinal lumen and enterocytes yield $90 \%$ of the protein in single amino acids and 10\% in di- and tripeptides [24]. Between the BPs selected in this work, IY, DE, and IPI were stated by Iwaniak and Mogut (2020) as potential to treat metabolic syndrome [25], most of the selected BPs are hydrophobic so paracellular absorption via the PEPT1 transporter could be a mechanism for their absorption [26].

Of all the sequences assessed, Concanavalin B showed the higher number of BPs, this protein belongs to the quitinase family with $44 \%$ of essential amino acids and a TIM-barrel like structure [27]. To the best of our knowledge Concanavalin B has not been studied in the BPs context.

With the proposed modifications we expect the release of 15 BPs with activity against the major metabolic disturbances present in the metabolic syndrome.

\subsection{Expression and Purification}

The yields and productivities found for CNVR and CNV44 are similar, so modification in the sequence did not alter their expression. Production of proteins with therapeutic capacity for non-communicable disease is a serious concern and expression levels represent a crucial issue to care about. In this work the yield of CNV44 was $1460 \mathrm{mg} / \mathrm{L}$, other food proteins expressed in E. coli BL21 strain report expression levels of $480.8 \mathrm{mg} / \mathrm{L}$ for 
the GST-IY-VKY multimer [28] and $675 \mathrm{mg} / \mathrm{L}$ for the PTHIKWGD multimer [29]. The expression levels for CNV44 reported in this work $(1460 \pm 20 \mathrm{mg} / \mathrm{L})$ are superior. In silico work done may have had an impact in this fact, as stability and FFE parameters got good values and, the instability index as a predictor of in vitro environment; values below 40 are considered stable [30]. Most of these proteins have been purified in insoluble form, other strategies to express them in soluble form will be envisioned in future research.

\subsection{In Vitro Activity}

The inhibition of DPPH by the peptides released was really low; however, still, when comparing the proteins, it was observed that digested CNV44 showed the highest inhibition, being significantly different $(p<0.05)$ from the unmodified protein and the two proteins (CNV44 and undigested CNVR).

Regarding ABTS inhibition, the results showed a significant difference $(p<0.05)$ between digested CVN44 (CNV44dig) and the other treatments. There was no significant difference $(p<0.05)$ between undigested CNV44 protein and digested CNVR (CVNRdig). Although at high concentrations (above $200 \mathrm{ug} / \mathrm{mL}$ ) the digested unmodified protein (CVNRdig) also had favorable results, though much lower ( $50 \%)$ than the digested modified protein (CNV44dig). The increase in the number of antioxidant peptides may be the reason for the difference found between CNV44 and CNVR, as seen in the peptides presented in the results section. Undigested CNV44 had a very low antioxidant activity, but even so, it presented higher activity than undigested CNVR from $100 \mathrm{ug} / \mathrm{mL}$. CVNR protein did not inhibit free radical production.

Regarding the $\mathrm{Fe}^{+}$chelation, it was observed that digested CNV44 (CNV44Dig) had a significantly $(p<0.05)$ better activity than digested CNVR; from $100 \mathrm{ug} / \mathrm{mL}$, approximately $20 \%$ higher $\mathrm{Fe}^{+}$chelation. As with the DPPH and ABTS activities, this could demonstrate the success of the design, as a greater presence of antioxidant peptides would be found, although more studies are necessary to confirm the identity of the released peptides. Between the undigested proteins (CNV44 and CNVR) there was no significant difference.

CNVR and CNV44 hydrolysates increased the antioxidant activity in the three tested techniques. In order to exert their biological activities, bioactive peptides have to be released from their parental proteins sequences because the conformation of the side chains as well as the liberated C- and $\mathrm{N}$-terminal groups responsible for their activity [5], are buried in the structure of the proteins that contain them [31]. The antioxidant activity depends on the techniques used to assess it; while the ABTS and Iron chelation tests showed that hydrolysates have an activity greater than $50 \%$, DPPH does not exceed $10 \%$. It is common, but not a rule, that DPPH and ABTS techniques tend to show similar results, however a couple of studies $[32,33]$ have shown that even though both techniques report on electron transfer [34] higher activities have been obtained with ABTS, as it is observed in this work, especially when lipophilic compounds increase, as it happened with modifications to the $\mathrm{CNV}$ sequence where apolar amino acids were introduced.

Research in bioactive peptides is focused on finding the most viable strategies to obtain the highest activities, in general the hydrolysates under different enzymatic hydrolysis schemes are the most used strategies over others, like physical methods or SGID. The maximum percentage of antioxidant activities found in this work at $400 \mu \mathrm{g} / \mathrm{mL}$ were $10 \%$ for DPPH, $83.7 \%$ for ABTS and $77.5 \%$ for chelation. Tang et al. [35] hydrolyzed zein with alcalase and observed $100 \%$ inhibition of DPPH and $73.5 \%$ of ABTS blenching at $50 \mathrm{mg} / \mathrm{mL}$, the lowest concentration tested was $1 \mathrm{mg} / \mathrm{mL}$ where they obtained $12.8 \%$ and $64.3 \%$ for DPPH and ABTS, respectively. In a recent work, Goncalves et al. (2020) hydrolyzed a cotton seed by-product with alcalase, neutrase, and flavourzyme; they reported activities greater than $95 \%$ of DPPH inhibition at concentration of $3 \mathrm{mg} / \mathrm{mL}$ [36], that represent 7.5 times the concentration used in this works. ABTS antioxidant activity reported here is similar to the reported by Karamac et al. [37] a result achieved with $2 \mathrm{mg} / \mathrm{mL}, 5$ times higher than those used in present work. 
Teixeira et al. [38] reported a carp muscle hydrolysate by SGID and found similar activities than those reported in present work but using a concentration 5 times higher. Likewise, they reported $80 \%$ of chelation at $4 \mathrm{mg} / \mathrm{mL}$, a concentration 10 times higher than that used here. Zhang et al. [39] prepared a soy protein hydrolysate with alcalase and after subjected it to SGID, they found increased antioxidant activities except for ABTS. Their results are like those present here; however, their activities were obtained with concentrations between 2.5 to 12.5 times higher than those used in the present work.

Antioxidant peptides have been thoroughly studied. Due to the large number of techniques used to evaluate them, it is very difficult to find trends in terms of their structurefunction relationships; nevertheless, one common rule is that smaller peptides exhibit higher activities [40]. It has been proposed that hydrophobic amino acids, specifically aromatics, are key factor for high antioxidant activity [41,42]. In this work, the designed protein was endowed with the DW peptide, in addition to multiple VY, also reported with antioxidant activity [19], both peptides meet the structural requirements previously described.

Regarding the angiotensin converting enzyme inhibitory activity, the statistical analysis showed that CNV44 had an inhibitory effect on ACE, significantly greater $(p<0.05)$ than the recombinant protein without modification (CNVR). A significant difference was found between the undigested proteins with respect to the digested ones; being the higher inhibition in the digested proteins; which agrees with the fact that it is necessary for the peptides to be released from their original sequence, so that they can exert activity. When comparing the two undigested proteins, there was no significant difference between them. This is because the peptides are encrypted in the protein sequences.

Antihypertensive activity is by far the most studied effect of bioactive peptides; all protein sources have been used to generate BPs [43]. In 2002, Pedroche et al. hydrolyzed pea protein isolate with alcalase and flavourzyme, the highest inhibition reported was $40 \%$ [44]. In 2009 Je et al. [45] hydrolyzed prickly pear liver with multiple enzymes, their best hydrolysate reached 36\% of inhibition. In 2015, Magaña et al. [46] obtained hydrolysates from Phaseolus lunatus and some fractions had inhibition percentage above $50 \%$ and reported IC50 values in the range of 0.9 to $3.8 \mu \mathrm{g} / \mathrm{mL}$, Daliri et al. [47] report $88 \%$ of ACE inhibition and IC50 of $0.59 \mathrm{mg} / \mathrm{mL}$ from soy protein hydrolysates. Garlic protein hydrolysates reported by Gao et al. [48] have IC50 of $0.89 \mathrm{mg} / \mathrm{mL}$; finally, in 2020, Suwannapan et al. [49] studied the effect of SGID on the ACEI activity of rice protein, finding that ACE inhibition does not reach $30 \%$. None of these studies reached the percentage of inhibition or IC50 found for the CNV44 hydrolysate, except for the report by Magaña; however, in the present work, we tested the complete hydrolysates and not fractions as Magaña et al.

According to the design of the CNV44 protein, the presence of ACE inhibitor peptides increased from 5 to 12 including 4 VY, the ACEI peptide with the highest activity reported to date. This increase in the number of ACEI peptides could be responsible for the increase in activity found in the present work.

Regarding the inhibition of the DPPIV enzyme, it was observed that up to $50 \mathrm{ug} / \mathrm{mL}$, there was a significant difference $(p<0.05)$ between digested CNV44 and digested CNVR; although the difference was only $\sim 11 \%$. There was a clear difference between digested and undigested proteins. This is because it is necessary for the peptides to be released from their original sequence, so that they can exert activity. Between undigested CNVR and undigested CNV44 there was no significant difference.

Peptides with DPPIV inhibitory activity have not received much attention, however, some interesting studies are found in the literature; Jia et al. [50] prepared trypsin hydrolysates from $\alpha$-lactalbumin varying parameters and subsequently subjecting to SGID, they reported IC50 values in the range of 0.41 to $0.61 \mathrm{mg} / \mathrm{mL}$, for samples most extensively hydrolyzed. DPPIV inhibitory activity has been assessed in other hydrolyzed proteins. Hsu et al. [51] reported that skin porcine gelatin hydrolyzed with alcalase reaches an IC50 of $0.06 \mathrm{mg} / \mathrm{mL}$; Lafarga and Hayes [52] reported a bovine lung hydrolyzed with high 
pressure + alcalase showing an IC50 of $1.43 \mathrm{mg} / \mathrm{mL}$. More recently, two studies $[53,54]$ reported treatments with SGID after enzymatic pretreatments, showing IC50 of $4 \mathrm{mg} / \mathrm{mL}$ from sardine muscle and $0.23 \mathrm{mg} / \mathrm{mL}$ from boarfish. The hydrolysates of the present work presented an IC50 lower than those reported in literature, only comparable with those obtained by Hsu et al. [51]. The results published by other authors are between 1.4 to 90 times higher than those found for the CNV44 hydrolysate.

The designed protein CNV44, has only one peptide (IPI) exclusive for DPPIV inhibition, the addition of this peptide to the $\mathrm{C}$-term could be responsible for the differences between CNVR and CNV44 hydrolysates, this tripeptide is the peptide with better activity reported against DPPIV, it presents an IC50 of $3.2 \mu \mathrm{M}$ [55].

HMGR is an enzyme that catalyzes the reduction of HMG-CoA to mevalonate [56]; its inhibition can be detected by NADPH consumption [57]. In the present work, NADPH consumption falls after $10 \mathrm{~min}$ and is similar to that reported for Manólio Soares et al. [58]. There was no significant difference in the NADPH oxidation rate between undigested CNVR, digested CNVR, and undigested CNV44. While digested CNV44 showed the lowest oxidation rate of NADPH, being significantly different $(p<0.05)$ than the other proteins, showing higher inhibitory activity of HMGR at $100 \mathrm{ug} / \mathrm{mL}$.

The designed protein has only one lipid-lowering peptide (DE) with previously reported activity, although the impact on this activity can be attributed to this peptide, a dual action by some of the other added peptides cannot be ruled out; furthermore, this peptide is the only one with the structural characteristics and constraints that we established for peptide selection, more research in lipid lowering-peptide is needed in order to improve this particular activity.

It has been reported that soy protein digested with papain + alcalase and subsequent subjected to SGID present antioxidant and ACEI activity as well as DPPIV inhibition [59], showing a maximum ACEI activity of $20.3 \%$, a $2.73 \mathrm{mg} / \mathrm{mL}$ IC50 for DPPIV inhibition; and a $5.3 \mathrm{mg} / \mathrm{mL}$ IC50 for antioxidant activity. After digestion, all activities increased to values above $70 \%$, always in the order of $\mathrm{mg} / \mathrm{mL}$, while in the present work IC50 values are 100 times lower. To the best of our knowledge, the modification of Concanavalin B presented in this work, is the first attempt to engineer a protein to specifically treat or ameliorate metabolic syndrome. Nevertheless, this is only the first step, further studies are required to assess the effect of the modified proteins at the organismal level, because protein hydrolysates assayed in vitro do not necessarily have the same effects in vivo. In addition, all the interpretations of the results described above were related to the properties of the engineered dipeptides, nevertheless the enhanced effects might also be due to other unexpected bioactive sequences released.

\section{Conclusions}

In this work, we present the first in vitro evidence of a modified protein with the potential to treat metabolic syndrome. Modified CNV44 achieved better results than non-modified CNVR and these activities improved after SGID, where CNV44 digested performed better in all the activities tested. Because the biological activities of this protein increase after being digested with gastrointestinal enzymes, this makes it a potential treatment with oral administration; therefore, we developed and tested a new strategy for the design of proteins that can be used for the treatment of other non-communicable disease based on bioactive peptides.

Supplementary Materials: The following are available online at https:/ /www.mdpi.com/article/10 .3390/foods10071554/s1, Table S1: Frequency of selected bioactive peptides in vegetable proteins and their A number. Table S2: The 96 sequences of $\mathrm{CNV}$ with a total of 13 modifications generated, Figure S1: PCR product of concanavalin B extracted from leaves, Figure S2: NADPH stability in phosphate buffer $\mathrm{pH} 7.4$ and EDTA $200 \mathrm{mM}$.

Author Contributions: Conceptualization, D.A.M.-T., D.A.F.-V. and S.L.-S.; Formal analysis, D.A.M.T. and D.A.F.-V.; Funding acquisition, S.L.-S.; Investigation, D.A.M.-T. and S.L.-S.; Methodology, 
D.A.M.-T. and G.J.J.-R.; Project administration, G.J.J.-R. and S.L.-S.; Resources, S.L.-S.; Supervision, F.d.F.R.-C. and S.L.-S.; Validation, S.L.-S.; Visualization, D.A.M.-T. and D.A.F.-V.; Writing-original draft, D.A.M.-T.; Writing—review and editing, D.A.M.-T., F.d.F.R.-C., D.A.F.-V. and S.L.-S. All authors have read and agreed to the published version of the manuscript.

Funding: This publication was supported by Secretaría de Investigación y Posgrado and co-financed by Consejo Nacional de Ciencia y Tecnología (CONACyT).

Institutional Review Board Statement: Not applicable for studies not involving humans or animals. Informed Consent Statement: Not applicable.

Data Availability Statement: The data presented in this study are available on request from the corresponding author.

Acknowledgments: We thanks to the Secretaría de Investigación y Posgrado and Consejo Nacional de Ciencia y Tecnología (CONACyT) for the scholarship to D.A.M.T.

Conflicts of Interest: The authors declare no conflict of interest.

\section{References}

1. McKeown, R.E. The epidemiologic transition: Changing patterns of mortality and population dynamics. Am. J. Lifestyle Med. 2009, 3 (Suppl. 1), 19S-26S. [CrossRef]

2. Grundy, S.M. Metabolic syndrome update. Trends Cardiovasc. Med. 2016, 26, 364-373. [CrossRef] [PubMed]

3. Granato, D.; Barba, F.J.; Kovacevic, D.; Lorenzo, J.M.; Cruz, A.; Putnik, P. Functional Foods: Product development, Technological trends, Efficacy testing and Saefty. Annu. Rev. Food Sci. Technol. 2020, 11, 93-118. [CrossRef] [PubMed]

4. Rajasekaran, A.; Kalaivani, M. Designer foods and their benefits: A review. J. Food Sci. Technol. 2013, 50, 1-16. [CrossRef]

5. Sánchez, A.; Vázquez, A. Bioactive peptides: A review. Food Qual. Saf. 2017, 1, 29-46. [CrossRef]

6. Bhandari, D.; Rafiq, S.; Gat, Y.; Gat, P.; Waghmare, R.; Kumar, V. A review on bioactive peptides: Physiological functions, bioavailability and safety. Int. J. Pept. Res. Ther. 2019, 26, 139-150. [CrossRef]

7. Takenaka, Y.; Utsumi, S.; Yoshikawa, M. Introduction of enterostatin (VPDPR) and a related sequence into soybean proglycinin $\mathrm{A}_{1 \mathrm{a}} \mathrm{B}_{1 \mathrm{~B}}$ subunit by site-directed mutagenesis. Biosci. Biotechnol. Biochem. 2000, 64, 2731-2733. [CrossRef] [PubMed]

8. Shengqi, R.; Xu, Z.; Su, Y.; Li, J.; Sung, J.; Yang, Y. Cloning, soluble expression and production of recombinant antihypertensive peptide multimer (AHPM-2) in Escherichia coli for bioactivity identification. Protein Pept. Lett. 2011, 18, 699-706. [CrossRef]

9. Maldonado-Torres, D.A.; Fernández-Velasco, D.A.; Morales-Olán, G.; Rosas-Cardenas, F.F.; Luna-Suárez, S. Modification of vegetables proteins to release bioactive peptides able to treat metabolic syndrome-In silico assessment. Appl. Sci. 2020, 10, 2604. [CrossRef]

10. Minkiewicz, P.; Dziuba, J.; Iwaniak, A.; Dziuba, M.; Darewicz, M. BIOPEP database and other programs for processing bioactive peptide sequences. J. AOAC Int. 2008, 91, 965-980. [CrossRef]

11. Schlesier, B.; Nong, V.; Hortsmann, C.; Henning, M. Sequence analysis of Concanavalin B from Canavalia ensiformis reveals homology to chitinases. J. Plant Physiol. 1996, 147, 665-674. [CrossRef]

12. Espinosa-Hernández, E.; Morales-Camacho, J.I.; Fernández-Velasco, D.A.; Benítez-Cardoza, C.G.; Rosas-Cárdenas, F.F.; LunaSuárez, S. The insertion of bioactive peptides at the C-terminal end of an $11 \mathrm{~S}$ globulin changes the structural stability and improves the antihypertensive activity. Electron. J. Biotechnol. 2019, 37, 18-24. [CrossRef]

13. Laemmli, U.K. Cleavage of structural proteins during the assembly of the head of bacteriophage T4. Nature 1970, 227, 680-685. [CrossRef] [PubMed]

14. Vilacundo, R.; Miralles, B.; Carrillo, W.; Hernández-Ledesma, B. In vitro chemopreventive properties of peptides released from quinoa (Chenopodium quinoa Wild) protein under simulated gastrointestinal digestion. Food Res. Int. 2018, 105, 403-411. [CrossRef] [PubMed]

15. Ajibola, C.F.; Fashakin, J.B.; Fagbemi, T.N.; Aluko, R.E. Effect of peptide size on antioxidant properties of African Yam Bean Seed (Sphenostylis stenocarpa) protein hydrolysate fraction. Int. J. Mol. Sci. 2011, 12, 6685-6702. [CrossRef] [PubMed]

16. Re, R.; Pellegrini, N.; Pretggente, A.; Pannala, A.; Yang, M.; Rice-Evans, C. Antioxidant activity applying an improved ABTS radical cation decolorization assay. Free Radic. Biol. Med. 1999, 26, 1231-1237. [CrossRef]

17. Adjimani, J.P.; Asare, P. Antioxidant and free scavenging activity of iron chelators. Toxicol. Rep. 2015, 2, 721-728. [CrossRef]

18. Li, G.; Liu, H.; Shi, Y.; Le, G. Direct spectrophotometric measurement of angiotensin-I converting enzyme inhibitory activity for screening bioactive peptides. J. Pharm. Biomed. Anal. 2005, 37, 219-224. [CrossRef]

19. Lacroix, I.M.E.; Li-Chan, E.C.Y. Dipeptidyl peptidase-IV inhibitory activity of dairy protein hydrolysates. Int. Dairy J. 2012, 25, 97-102. [CrossRef]

20. Lin, S.H.; Chang, D.K.; Chou, M.J.; Huang, K.J.; Shihuam, D. Peptide inhibitors of human HMG-CoA reductase as potential hypocholesterolemia agents. Biochem. Biophys. Res. Commun. 2014, 459, 105-109. [CrossRef]

21. Cheng, Y.; Chen, J.; Xiong, Y.L. Chromatographic separation and tandem MS identification of active peptides in potato protein hydrolysate that inhibit autooxidation of soybean oil-in-water emulsions. J. Agric. Food Chem. 2010, 58, 8825-8832. [CrossRef] 
22. Saito, Y.; Wanezaki, K.; Kawato, A.; Imayasu, S. Structure and activity of angiotensin I converting enzyme inhibitory peptides from sake and sake less. Biosci. Biotech. Biochem. 1994, 58, 1767-1771. [CrossRef] [PubMed]

23. Jiang-Bo, T.; Jia, C.; Shu-Ling, L.; Min, B. A quantitative structure-activity relationship (QSAR) study of peptide drugs based on a new descriptor of amino acids. J. Serb. Chem. Soc. 2015, 80, 343-353. [CrossRef]

24. Ganapathy, V.; Gupta, N.; Martindale, R.G. Protein digestion and Absorption. In Physiology of the Gastrointestinal Tract; Jhonson, L.R., Ed.; Academic Press: Cambridge, MA, USA, 2006; pp. 1667-1692.

25. Iwaniak, A.; Mogut, D. Metabolic syndrome-preventing peptides derived from milk proteins and their presence in cheeses: A review. Appl. Sci. 2020, 10, 2772. [CrossRef]

26. Wang, R.; Xie, N.; Li, B. Influence of peptide characteristics on their stability, intestinal transport, and in vitro bioavailability: A review. J. Food Biochem. 2018, E12571. [CrossRef] [PubMed]

27. Morrison, R.; DeLozier, G.; Robinson, L.; McPherson, A. Bochemical and X-Ray diffraction analysis of Concanavalin B crystals from Jack Bean. Plant Physiol. 1984, 76, 175-183. [CrossRef]

28. Oh, K.S.; Park, Y.S.; Sung, H.C. Expression and purification on an ACE-inhibitory peptide multimer from synthetic DNA in Escherichia coli. J. Microbiol. Biotechnol. 2002, 12, 56-64. [CrossRef]

29. Fida, H.; Kumada, Y.; Terashima, M.; Katsudo, T.; Katoh, S. Tandem multimer expression of angiotensin-I converting enzyme inhibitory peptide in Escherichia coli. Biotechnol. J. 2009, 4, 1345-1356. [CrossRef]

30. Guruprasad, K.; Reddy, B.V.B.; Pandit, M.W. Correlation between stability of a protein and its dipeptide composition: A novel approach for predicting in vivo stability of a protein from its primary sequence. Protein Eng. 1990, 4, 155-161. [CrossRef]

31. Karami, Z.; Akbari-Adergani, B. Bioactive food derived peptides: A review on correlation between structure of bioactive peptides and their functional properties. J. Food Sci. Technol. 2019, 56, 535-547. [CrossRef]

32. Floegel, A.; Kim, D.; Chung, S.; Koo, S.; Chun, O. Comparison of DPPH/ABTS assay to measure antioxidant capacity in popular antioxidant-rich U.S. foods. J. Food Compos. Anal. 2011, 24, 1043-1048. [CrossRef]

33. Muller, L.; Frohlich, K.; Bohm, V. Comparative antioxidant activities of carotenoids measured by ferric reducing antioxidant power (FRAP), ABTS bleaching assay ( $\alpha$ TEAC), DPPH assay and peroxyl radical scavenging assay. Food Chem. 2011, 129, 139-148. [CrossRef]

34. Huang, D.; Ou, B.; Prior, R. The chemistry behind antioxidant capacity assays. J. Agric. Food Chem. 2005, 53, 1841-1856. [CrossRef]

35. Tang, X.; He, Z.; Dai, Y.; Xiong, Y.; Xie, M.; Chen, J. Peptide fractionation and free radical scavenging activity of zein hydrolysate. J. Agric. Food Chem. 2010, 58, 587-593. [CrossRef] [PubMed]

36. Goncalves, J.; Moraes, J.; Fernandes, A.C.; Borges, A.; Valencia, E.; Fernandes, K.; Lemes, A.; Fernandes, C.; de Figuereido, H.; Rosa da Silva, E.; et al. Bioactive properties of protein hysrolysate of cottonseed byproduct: Antioxidant, antimicrobial, and angiotendin converting enzyme (ACE) inhibitory activities. Waste Biomass Valorization 2020, 12. [CrossRef]

37. Karamac, M.; Kosinska-Cagnazzo, A.; Kulczyk, A. Use of different proteases to obtain flaxseed protein hydolysates with antioxidant activity. Int. J. Mol. Sci. 2016, 17, 1027. [CrossRef]

38. Teixeira, B.; Pires, C.; Nunes, M.; Batista, I. Effect of in vitro gastrointestinal digestion on the antioxidant activity of protein hydrolysates prepared for Cape hake by-products. Int. J. Food Sci. Techol. 2016, 51, 2528-2536. [CrossRef]

39. Zhang, Q.; Tong, X.; Qi, B.; Wang, Z.; Li, Y.; Sui, X.; Jiang, L. Changes in antioxidant activity of alcalase-hydrolysed soybean hydrolysate under simulated gastrointestinal digestion and transepithelial transport. J. Funct. Foods 2018, 42, 298-305. [CrossRef]

40. Zou, T.; He, T.; Li, H.; Tang, H.; Xia, E. The structure activity relationship of the antioxidant peptides from natural proteins. Molecules 2016, 21, 72. [CrossRef]

41. Saidi, S.; Deretani, A.; Belleville, M.; Amar, R. Antioxidant properties of peptide fractions from tuna dark muscle protein by-product hydrolysate produced by membrane fractionation process. Food Res. Int. 2014, 65, 329-336. [CrossRef]

42. Girgih, A.; He, R.; Malomo, S.; Offengeden, M.; Wu, J.; Aluko, R. Structural and functional characterization of hemp seed (Cannabis sativa L.) protein-derived antioxidant and antihypertensive peptides. J. Funct. Foods 2014, 6, 384-394. [CrossRef]

43. Kaur, A.; Adesgun, K.B.; Sharma, P.; Sharma, D.; Kaur, S. Recently isolated food-derived antihypertensive hydrolysates and peptides: A review. Food Chem. 2021, 346, 128719. [CrossRef]

44. Pedroche, J.; Yust, M.; Girón-Calle, J.; Alaiz, M.; Millán, F.; Vioque, J. Utilization of chickpea protein isolates for production of peptides with angiotensin-Iconverting enzyme (ACE)-inhibitory activity. J. Sci. Food Agric. 2002, 82, 960-965. [CrossRef]

45. Je, J.Y.; Lee, K.H.; Lee, M.H.; Ahn, C. Antioxidant and antihypertensive protein hydrolysates produced from tuna liver by enzymatic hydrolysis. Food Res. Int. 2009, 49, 1266-1272. [CrossRef]

46. Magaña, M.D.; Segura-Campos, M.; Dávila-Ortiz, G.; Betancour-Ancona, D.; Chel-Guerrero, L. ACE-I inhibitory properties of hydrolysates from germinated and ungerminated Phaseolus lunatus proteins. Food Sci. Technol. 2015, 35, 167-174. [CrossRef]

47. Daliri, E.; Odusu, E.K.; Chelliah, R.; Park, M.H.; Kim, J.H.; Oh, D.H. Development of soy protein hydrolysate with an antihypertensive effect. Int. J. Mol. Sci. 2019, 20, 1496. [CrossRef]

48. Gao, X.; Xue, Z.; Ma, Q.; Guo, Q.; Xing, L.; Santhanam, R.K.; Zhang, M.; Chen, H. Antioxidant and antihypertensive effects of garlic protein and its hydrolysates and the related mechanism. J. Food Biochem. 2019, 44, e1312. [CrossRef]

49. Suwannapan, O.; Wachirattanapongmette, K.; Thawornchinsombut, S.; Katekaew, S. Angiotensin-I-converting enzyme (ACE)inhibitory peptides from Thai jasmine rice bran protein hydrolysates. Int. J. Food Sci. Technol. 2020, 55, 2441-2450. [CrossRef] 
50. Jia, C.; Hussain, N.; Ujiroghene, O.; Pang, X.; Zhang, S.; Lu, J.; Liu, L.; Lu, J. Generation and characterization of dipeptidyl peptidase-IV inhibitory peptides from trypsin -hydrolyzed $\alpha$-lactalbumin-rich whey proteins. Food Chem. 2020, $318,126333$. [CrossRef]

51. Hsu, K.; Tung, Y.; Huang, S.; Jao, C. Dipeptidyl peptidase-IV inhibitory activity of peptides in porcine skin gelatine hydrolysates. In Bioactive Food Peptides in Health and Disease, 1st ed.; Hernandes-Ledesma, B., Hsie, C., Eds.; IntechOpen: London, UK, 2013. [CrossRef]

52. Lafarga, T.; Hayes, M. Effect of pre-treatment on the generation of dipeptidyl peptidase-IV and prolyl endopeptidase-inhibitory hydrolysates from bovine lung. Irish J. Agric. Food Res. 2017, 56, 12-24. [CrossRef]

53. Rivero-Pino, F.; Espejo-Carpio, F.J.; Guadix, E. Production and identification of dipeptidyl peptidase IV (DPPIV) inhibitory peptides from discarded Sardine pilchardus protein. Food Chem. 2020, 328, 127096. [CrossRef] [PubMed]

54. Harnedy-Rotwell, P.; McLaughlin, C.; O’Keffe, B.; Le Gouic, A.; Allsopp, P.; McSorley, E.; Sharkey, S.; Whooley, J.; McGovern, B.; O'Harte, F.; et al. Identification and characterization of peptides from boarfish (Capros aper) protein hydrolysate displaying In vitro dipeptidyl peptidase-IV (DPP-IV) inhibitory and insulinotropic activity. Food Res. Int. 2020, 131, 108989. [CrossRef] [PubMed]

55. Nogonierma, A.; FitzGerald, R. Features of dipeptidyl peptidase IV (DPP-IV) inhibitory peptides from dietary proteins. J. Food Biochem. 2017, 43, e1245. [CrossRef]

56. Istvan, E.; Paltnikar, M.; Buchanan, S.; Disenhofer, J. Crystal structure of the catalytic portion of human HMG-CoA reductase: Insights into regulation activity and catalysis. EMBO J. 2000, 19, 819-830. [CrossRef]

57. Holdgate, H.A.; Ward, W.H.J.; McTaggart, F. Molecular mechanism for inhibition of 3-hydroxy-3-methylglutaryl CoA (HMG-CoA) reductase by rosuvastatin. Biochem. Soc. Trans. 2003, 31, 528-531. [CrossRef]

58. Manólio Soares, R.A.; Mendoca, S.; Andrade de Castro, L.I.; Menezes, A.C.; Gomes Areas, J.A. Major peptides from amaranth (Amaranthus cruentus) protein inhibit HMG-CoA reductase activity. Int. J. Mol. Sci. 2015, 16, 4150-4160. [CrossRef]

59. Wang, R.; Zhao, H.; Pan, X.; Orfila, C.; Lu, W.; Ma, Y. Preparation of bioactive peptides with antidiabetic, antihypertensive and antioxidant activities and identification of $\alpha$-glucosidase inhibitory peptides from soy protein. Food Sci. Nutr. 2019, 7, 1848-1856. [CrossRef] 